\title{
MISTISISME ISLAM MODERN
}

\author{
M. Iqbal Nasir \\ Pascasarjana UIN Alauddin Makassar \\ iqbalmesja@gmail.com
}

\begin{abstract}
Abstrak: Penelitian ini mengkaji tentang mistisisme Islam modern. Problematika mistisme sering dipermasalahkan karena berhubungan dengan kepercayaan dan ilmu pengetahuan. Sikap para filosofof mengenai mistisisme sudah dibahas dan dijelaskan dalam buku-buku klasik tentang alam idea atau transendental. Permasalahan ini bukan permasalahan yang baru bagi para pemikir. Misitisisme dalam Islam juga dikaji dan dianalisa sehingga para pakar tasawuf membuat beberapa karya ilmiah mengenai mistisisme Islam dan dikembangkan pada abad modern. Hal tersebut masih bisa diterima dan diaplikasikan selama hal atau jalur dari sebuah tarekat sesuai dengan rambu-rambu syariat atau agama Islam. Mistisisme Islam ini dikaji secara tematik hingga menuju titik pendalaman materi serta menyinggung hal-hal yang terjadi pada zaman modern ini.
\end{abstract}

\begin{abstract}
This study examines the mysticism of modern Islam. The problem of mysticism is often disputed because it relates to belief and science. The philosophical attitudes of mysticism are discussed and explained in the classical books of the idea or transcendental nature. This problem is not a new problem for thinkers. The misitisism in Islam was also examined and analyzed so that the scholars of Sufism made some scientific work on Islamic mysticism and developed in the modern century. It can still be accepted and applied during the matter or path of a tarekat according to the signs of Sharia or Islamic religion. This Islamic mysticism is examined thematic to the point of deepening of the matter and alluding to the things that happen in this modern day.
\end{abstract}

Keywords. Mysticism; Islam; Modern

\section{PENDAHULUAN}

Mistisisme sering didengar bahkan kata tersebut tidak asing bagi kita. Mistisisme sering dipersoalkan dalam dunia pendidikan, bahkan dalam ajaranajaran agama di dunia, persoalan mistisisme selalu diangkat dalam kitab-kitab samawi, seperti dalam kitab Taurat, Injil, dan al-Qur'an. Kitab-kitab tersebut sering kali menyinggung hal-hal yang tidak dapat dilihat oleh mata dan bahkan sulit untuk diterima oleh akal manusia.

Permasalahan ini juga menuai tantangan yang besar karena perubahan zaman yang begitu luar biasa karena sudah mencapai puncak modernitas, perubahan ini sangat sulit untuk menerima hal mistik karena membutuhkan pembuktian akal karena juga ilmu pengetahuan sudah berkembang dan serba 
canggih. Bahkan perkembangan zaman juga menuntut pembuktian ilmiah tentang tujuan tuntunan ajaran agama terhadap suatu masalah.

Hal abstrak dan esoterik dalam dunia Islam marak diperbincangkan sehingga menarik untuk dibahas mengenai hal ini. Dapatkah ilmu mistik dalam suatu agama dapat dibuktikan dan dirasakan khususnya dalam Islam di era modern ini. Maka dalam penelitian ini yang menjadi pokok masalah adalah bagaiamana mistisme Islam modern?

\section{ONTOLOGI MISTISISME ISLAM}

\section{Pengertian dan Latar Belakang Mistisisme Islam}

Mistisisme berasal dari kata mistik yang artinya hal gaib. ${ }^{1}$ Mistisisme dalam Kamus Bahasa Indonesia, berasal dari kata mistik yaitu hal-hal gaib yang tidak terjangkau dengan akal manusia biasa. ${ }^{2}$ Dan kata mistis berarti sifat mistik, seperti ia tertarik untuk mempelajari hal-hal yang mistis. ${ }^{3}$ Jadi mistisisme adalah paham yang memberikan ajaran yang mistis atau yang abstrak.

Mistisisme dipadankan dengan istilah tasawuf. Mistisisme dalam dunia Islma dikenal dengan istilah tasawuf atau pada zaman Nabi Muhammad saw. disebut dengan ahl sl-suffah. Dalam al-Mu'jam al-Wasit, tasawwuf adalah metode sektarian, dengan landasan meninggalkan kesenangan dunia dan menghiasi diri dengan kemuliaan agar jiwa bersih dan mulia. ${ }^{4}$ Al-Jurjāni menjelaskan bahwa tasawuf memiliki beberapa makna yaitu:

a. Bahwa tasawuf adalah keadaan denga mengambil adab-adab syar'i secara zahir maka hukumnya dipandang dari zahir dalam batin, dan secara batin maka hukmnya dipandang dari batin dalam batin. Maka orang beradab mendapatkan kesempurnaan dari dua hukum tersebut.

b. Mazhab yang memiliki kedudukan tinggi yang tidak bercampur dengan gurauan.

c. Menjernihkan hati serta menjauhi sifat materialistis, menghilangkan sifat manusia (yang terlalu mencintai dunia), menjauhi sifat egoisme,

\footnotetext{
${ }^{1}$ Sebagaimana yang disebutkan Amīn al-Kurdi bahwa ketahuilah bahwa, sesungguhnya ilmu tasawuf adalah ilmu batin dan termasuk ilmu yang memiliki tempat dan keagungan dari ilmuilmu yang lain. Lihat Amin al-Kurdi, Tanwìr al-Qulūb fi Mu'āmalah 'Allām al-Guyūb (Sūriyyah: Dār al-Qalam al-'Arabī, 1991), h. 463.

${ }^{2}$ Pusat Bahasa Departemen Pendidikan Nasional, Kamus Bahasa Indonesia (Jakarta: Pusat Bahasa, 2008), h. 1032.

${ }^{3}$ Pusat Bahasa Departemen Pendidikan Nasional, Kamus Bahasa Indonesia, h. 1032.

${ }^{4}$ Ibrāāim Muṣtafā, dkk., al-Mu’jam al-Wasịt (Dār al-Da’wah), h. 529.
} 
menghilangkan sifat keterikatan dengan roh (jin atau syetan). Menghubungkan diri dengan ilmu hakikat serta mempergunakan yang bermanfaat untuk terhadap kekekalan (akhirat), dan menasehati semua umat berbibadah kepada Allah swt. sesuai dengan pemahaman ilmu hakikat dan mengikuti jejak rasul saw. dalam syariat.

d. Meninggalkan ikhtiar (tidak menjadikan dunia tujuan).

e. Bersungguh-sungguh dan mencintai Allah swt.

f. Menjaga indra dari pengaruh nafsu.

g. Berpaling (dari hawa nafsu).

h. Menjernihkan muamalah kepada Allah swt. yang asalnya adalah berpaling dari dunia.

i. Sabar dalam ketaatan dan larangan.

j. Pengabdian mulia dan meninggalkan kesusahan.

k. Mengambil hakikat dan perkataan yang penuh makna dan berputus asa terhadap genggaman manusia. ${ }^{5}$

Dalam sejarah Islam, kata sufi muncul pertama kali dalam sejarah pada pertengahan abad delapan masehi. Nama ini dipopulerkan oleh Jābir bin Hayyān penemu kimia Syiah dari Kufah. Sedangkan jamak kata ini yaitu șüfiyyah masyhur pada abad $189 \mathrm{H} / 814 \mathrm{M}^{6}$

Tasawwuf atau sufi menurut Abū Hamīd Ahmad al-Gazāi $\bar{i}$ adalah orang yang menganggap diri mereka adalah audiensi pilihan, golongan musyāhadah, dan mukāsyafah. ${ }^{7}$ Tasawuf berasal dari kata tașawwafa-yatașawwufutasawwufan. Orang yang bertasawuf adalah orang yang mensucikan dirinya lahir dan batin dalam suatu pendidikan etika (budi pekerti) dengan menempuh jalan atau dasar didikan tiga tingkat yang dalam istilah ilmu tasawuf dinamakan takhalli, tahalli, tajalli.

Adapun sufisme adalah tindakan yang harus dilewati seorang sufi yang hanya diketahui oleh Tuhan semata. Sedang ia harus senantiasa bersama Tuhan, dan dalam bentuk dan cara yang hanya diketahui oleh Tuhan semata. Sufisme adalah sepeuhnya disiplin diri. Sufisme adalah memiliki bukan sesuatu, dan dimiliki oleh bukan sesuatu. Sufisme bukanlah suatu sistem yang tersusun atas

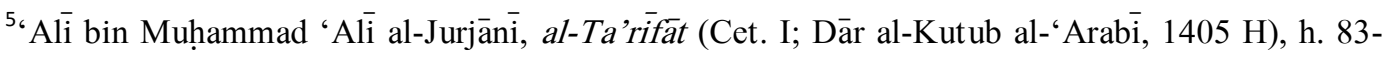
84.

${ }^{6}$ Iḥsān Ilāhī Zahīir. "al-Taṣawwuf: al-Mansya' wa al-Maṣādir”, al-Difǟ an al-Sunnah, http://www.d-sunnah.net

${ }^{7}$ Abū Hiamìd Ahmad al-Gazālì, Majmū'ah Rasāil al-Imām al-Gazāli : al-Munqiż min al-Ḍalāl, alAḥâdis al-Qudsiyyah, Qānūn al-Ta'wìl, Bairūt: Dār al-Kutub al-'Ilmiyyah, 1988), h. 31.

${ }^{8}$ Mustafa Zahri, Kunci Memahami Ilmu Tasawwuf(Jakarta: PT. al-Qusywa, 1985), h. 45.
} 
aturan ataupun sains, tetapi lebih merupakan aturan moral. Artinya ia dapat dijadikan milik seseorang dengan cara mempergunakannya. Dan apabila ia merupakan sains, tentu hanya akan diketahui melalui serangkaian instruksi. Tetapi sebagai anjuran, cobalah perhatikan, hiasilah dirimu dengan akhlak (sifat) Tuhan dan akhlak Tuhan itu tidak dapat diwujudkan hanya melalui serangkaian aturan ataupun sains. Sufisme adalah kebebasan dan kemurahan hati, dan dan ketiadaan hambatan pada diri sesorang. Sesungguhnya Tuhan akan mematikan mereka di dalam diri mereka dan akan menghidupkannya di dalam diriNya. Untuk mengatasi ketidaksempurnaan dunia, maka bukalah mata terhadap segala sesuatu yang tidak sempurna, dan dalam upaya merenungi dan mengingat Dia. Zat yang jauh dari ketidak sempurnaan itulah sefisme. Sufisme adalah penegndalian terhadap bagian-bagian tubuh, serta pengawasan terhadap kehidupan. Adalah sufisme yang akan menjauhkan yang ada di kepalaku, dan memberikan apa yang sudah ada di tanganmu, serta tidak akan mundur dari apa yang sudah dikaruniakan kepadanya. ${ }^{9}$

Dalam sejarah perkembangan mistisisme Islam yang pertama kali meletakkan tasawuf adalah Nabi Muhammad saw. yang berdasarkan wahyu dari Allah swt. berupa syariat pada umumnya dan dengan ilham kepada orang-orang khususnya. Kegiatan dan hasil-hasil yang dieproleh Nabi Muhammad saw. dengan tahannusnya di gua Hira dapat disimpulkan atas berbagai unsur: 1) melatih jasmani dengan banyak berjalan di atas bumi dan selalu menggerakkan tubuhnya, 2) melatih akal dan fikiran untuk memikirkan apa yang dalam batas maksimal sehingga beliau melupakan segala yang lain. Apabila seseorang itu telah sampai kepada taraf takut kepada Allah, maka segala yang lain dari Allah akan takut kepadanya, 3) melenyapka arti takut keseluruhannya dari perasaan dan pemikiran, 4) menimbulkan ingatan dan cinta yang bulat kepada Allah swt. ${ }^{10}$

Kehidupan Nabi Muhammad saw. itu adalah bahan yang kaya sekali bagi penulis sejarah. Beberapa orang ahli tärikh telah menulis buku yang tebal menguraikan kehidupan Nabi sebagai seoarang kepala perang, pembuka negeri. Dan penulis lain telah menguraikan pula bagaimana kehidupan sebagai orang yang menitik-beratkan pandangan hidup kepada kerohanian. Pakaiannya yang amat sederhana, makanannya yang hanya sekerat roti atau sebiji tamar yang diiringi seteguk air, dan ibadatnya, dan bangunnya tengah malam, dan pernah juga menangis dalam melakukan sembahyang semuanya adalah kehidupan Ideal,

\footnotetext{
${ }^{9}$ Reynold A. Nicholson, The Mistic of Islam, terj. Tim Penerjemah BA, Mistik dalam Islam (Cet. I; Jakarta: Bumi Aksara, 1998), h. 21.

${ }^{10}$ Mustafa Zahri, Kunci Memahami Ilmu Tasawwuf, h. 152.
} 
yang amat dirindui oleh ahli-ahli tasauf. Sehingga nabi pernah disindir Tuhan dalam al-Qur' an ${ }^{11}$ QS Ṭăhā/20: 1-2

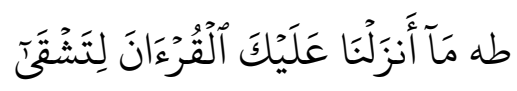

Terjemahnya:

Thaahaa, Kami tidak menurunkan Al Quran ini kepadamu agar kamu menjadi susah; ${ }^{12}$

Hamka berpendapat bahawa kerohanian yang membantu pendirian mereka, berkata bahwasanya pokok ambilan hidup kerohanian itu ialah agama Islma itu sendiri, dan juga kehidupan para sahabat-sahabatnya. Sebagaimana telah dijelaskan lebih dahulu tadi. Beberapa contoh cara pengambilan. QS alAnfāl ayat 17

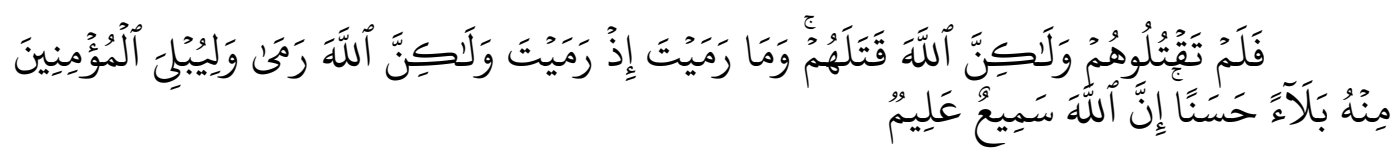

Terjemahnya:

Maka (yang sebenarnya) bukan kamu yang membunuh mereka, akan tetapi Allahlah yang membunuh mereka, dan bukan kamu yang melempar ketika kamu melempar, tetapi Allah-lah yang melempar. (Allah berbuat demikian untuk membinasakan mereka) dan untuk memberi kemenangan kepada orang-orang mukmin, dengan kemenangan yang baik. Sesungguhnya Allah Maha mendengar lagi Maha mengetahui.

Menurut pendapat kaum sufi, ayat ini adalah dasar yang kuat sekali dalam hidup kerohanian. Beberapa soal besar dalam tingkat-tingkat perjuangan kehidupan dapat disimpulkan dalam ayat ini. Yang melempar bukanlah Muhammad, melainkan Tuhan. Gerak dan gerik tidaklah ada pada kita, melainkan daripada Allah semata-mata. Kita bergerak dalam kehidupan ini hanyalah pada lahir belaka. Tidak ada yang terjadi kalau tidak izin Allah. Seorang hamba Allah dengan Tuhannya, hanyalah laksana sebuah kalam dalam tangan seorang penulis. Menulis karena digerakkan saja. Yang dituliskan tidak lain daripada kehendak penulis. QS al-Nūr ayat 35

\footnotetext{
${ }^{11}$ Hamka, Tasauf, Perkembangan dan Pemurniannya (Cet. X; Jakarta: Pustaka Panjimas, 1983), h. 28.

${ }^{12}$ Kementerian Agama RI, al-Qur'an dan Terjemahnya (Saudi Arabia: Mujamma' al-Malik Fahd li Thiba'at al-Mush-haf Asy-Syarif Medinah Munawwarah, 1997), h. 476.

${ }^{13}$ Kementerian Agama RI, al-Qur'an dan Terjemahnya, h. 263.
} 
Terjemahnya:

Allah (Pemberi) cahaya (kepada) langit dan bumi. ${ }^{14}$

Jadi adalah nur itu meliputi dan ada pada segala sesuatu, baik di langit atau di bumi, atau dimana saja. QS al-Baqarah ayat 115

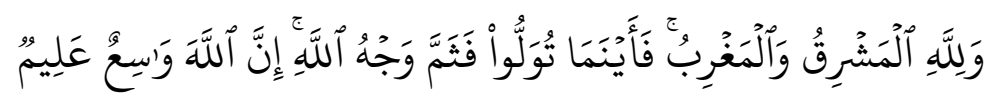

Terjemahnya:

Dan kepunyaan Allah-lah timur dan barat, Maka kemanapun kamu menghadap di situlah wajah Allah. Sesungguhnya Allah Maha Luas (rahmat-Nya) lagi Maha mengetahui. ${ }^{15}$

Pada kedua ayat itu kaum sufi berpegang keras bahwasanya alam ini adalah kesatuan semesta. Wahdah itu wujud atau kesatuan kesaktian (wahdah alsyuhūd), dan Allah itu tajalli pada setiap makhluknya. QS al-Māidah ayat 54

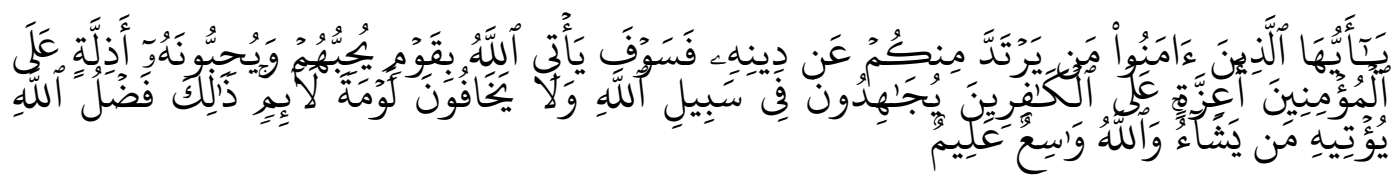

Terjemahnya:

Hai orang-orang yang beriman, Barangsiapa di antara kamu yang murtad dari agamanya, Maka kelak Allah akan mendatangkan suatu kaum yang Allah mencintai mereka dan merekapun mencintaiNya, yang bersikap lemah lembut terhadap orang yang mukmin, yang bersikap keras terhadap orang-orang kafir, yang berjihad dijalan Allah, dan yang tidak takut kepada celaan orang yang suka mencela. Itulah karunia Allah, diberikanNya kepada siapa yang dikehendaki-Nya, dan Allah Maha Luas (pemberian-Nya), lagi Maha mengetahui. ${ }^{16}$

QS al-Anbiyā' ayat 3

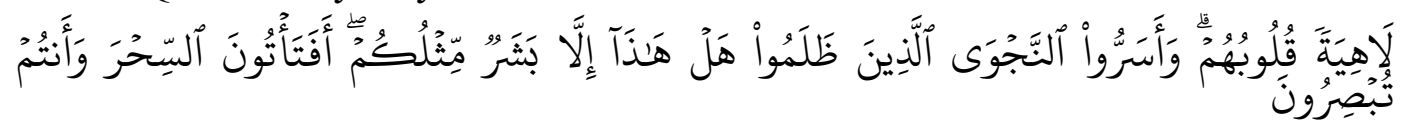

Terjemahnya:

(lagi) hati mereka dalam Keadaan lalai. dan mereka yang zalim itu merahasiakan pembicaraan mereka: "Orang ini tidak lain hanyalah seorang manusia (jua) seperti kamu, Maka Apakah kamu menerima sihir itu[951], Padahal kamu menyaksikannya?".

Kaum sufi menguatkan pendiriannya dengan ayat ini, bahwasanya asal mulanya segenap kejadian ini ialah al-haqiqah al-muhammadiyyah itulah dia al-

\footnotetext{
${ }^{14}$ Kementerian Agama RI, al-Qur'an dan Terjemahnya, h. 550.

${ }^{15}$ Kementerian Agama RI, al-Qur'an dan Terjemahnya, h. 31.

${ }^{16}$ Kementerian Agama RI, al-Qur'an dan Terjemahnya, h. 169.

${ }^{17}$ Kementerian Agama RI, al-Qur'an dan Terjemahnya, h. 495.
} 
ta'ayyun al-awwal ketentuan pertama dari segenap ketentuan yang tinggi dan rendah. Kemudian barulah dipisah-pisahkan antara satu dan lain, di antaranya adalah pisahan langit dan bumi. Pokok ajaran kaum sufi adalah segala sesuatu terikat dalam kesatuan raya, tidak ada perpisahan. Adapun perpisahan itu hanyalah pada rupa dan warna belaka. Adapun hakikatnya adalah esa, dan tangkai segenap kejadian adalah hakikat Muhammadiyah adalah sumber segala yang jadi. ${ }^{18}$

Ilmu tasawuf menerangkan bahwa syariat itu hanyalah peraturanperaturan belaka, tarekatlah yang merupakan perbuatan untuk melaksanakan syariat itu. Apabila syariat dan tarikat itu sudah dapat dikuasai, maka lahirlah hakikat yang tidak lain daripada perbaikan keadaan dan ahwal, sedang tujuan adalah makrifat yaitu mengenal Tuhan dan mencintainya dengan sebenarbenarnya dan sebaik-baiknya. ${ }^{19}$

Adapaun penjelasan tarikat dalam ilmu tasawwuf adalah jalan atau petunjuk dalam melakukan sesuatu ibadah sesuai dengan ajaran yang dicontohkan oleh Nabi Muhammad saw. dan dikerjakan oleh sahabat-sahabat nabi, tabi'in dan tabi'-tabi'in turun-termurun sampai kepada guru-guru/ulamaulama sambung-menyambung dan rantai-berantai sampai pada masa kita ini. ${ }^{20}$

Selanjutnya tokoh-tokoh yang masyhur dalam ilmu tasawuf adalah Hasan Basri, Sufyan al-Sauri, Abu Hasyim Sufi al-Kufi, al-Hallaj bin Muhammad alBaidawi dan lain-lain. Pada tahun $150 \mathrm{H}$ barulah kerohanian itu menjadi ilmu yang berdiri sendiri yang dinamakan ilmu tasawuf. ${ }^{21}$

Adapun kaum sufi dari kaum wanita adalah Rabi'ah al-'Adawiyyah, Mu'azah al-'Adawiyyah, Majidah al-Qurasyiyyah, Sayyidah 'Aisyah binti Ja'far Sadiq, Fatimah al-Naisburiyyah, Rabi'ah binti Isma'il, Ummu Harun, Ufairah alAbidah, Sya'ranah, Aminah al-Ramliyyah, Manfusah binti Zaid, Sayyidah Nafisah. $^{22}$

Pada abab ke tiga dan empat hijriah terdapat beberapa yang masyhur di

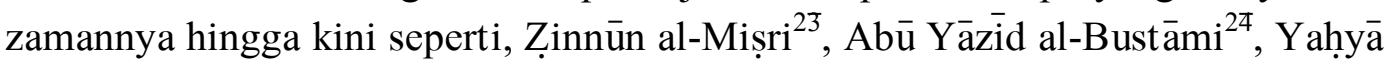

\footnotetext{
${ }^{18}$ Hamka, Tasauf, Perkembangan dan Pemurniannya, h. 39-40.

${ }^{19}$ Mustafa Zahri, Kunci Memahami Ilmu Tasawwuf, h. 57.

${ }^{20}$ Abu Bakar Aceh, Pengantar Ilmu Tarekat, dalam Mustafa Zahri, Kunci Memahami Ilmu Tasawwuf(Jakarta: PT. al-Qusywa, 1985), h. 56.

${ }^{21}$ Mustafa Zahri, Kunci Memahami Ilmu Tasawwuf, h. 53.

${ }^{22}$ Hamka, Tasauf, Perkembangan dan Pemurniannya, h. 84.

${ }^{23}$ Hamka, Tasauf, Perkembangan dan Pemurniannya, h. 99.
} 
bin Mu'āz ${ }^{25}$, al-Junaìd ${ }^{26}$, Abū Bakr Syibli ${ }^{27}$. Kemudian pada abad kelima lahirlah seorang ahli sufi yang melegenda dengan kapasitas ilmu yang luar biasa sehingga diberi gelar hujjatulislām al-Imām al-Gazāli ${ }^{28}$. Selanjutnya pada abad enam dan tujuh tasawuf mengalami kemajuan pesat dalam ilmu pengetahuan. Pertumbuhan fikiran-fikiran mendalam dari Ibn 'Arabī, Ibn Sabi'ìn Jalāluddin al-Rūmì, Ibn alFārị̣ dan lain-lain maka pertumbuhan tarikat-tarikat sulūk tidak menurun. Tarikat sulūk laksana pesantren kita sekarang ini. ${ }^{29}$ Di abad ini muncul pula Suhrawardi yang dikenal dengan sebutan al-Syaìkh al-Maqtūl. ${ }^{30}$ Kisaran abad tujuh dan delapan meratalah gerakan tasawuf, terutama dengan adanya tarikattarikat. Dalam ringkasan Ensiklopedi Islam, susunan Prof. Gibb, telah beliau daftarkan nama-nama tarikat itu selengkap-;engkapnya, berpuluh bahkan beratesratus banyaknya, yang telah berdiri sebelum bangsa Mogul menghancurkan Bagdad (656 H/1258 M). Tarikat-tarikat ini telah banyak dan telah bercabangcabang sejak abad empat belas milady, sejak dari Senegal di barat sampai ke negeri Tiongkok di timur. ${ }^{31}$

Beberapa sumber referensi kitab yang ditulis oleh para pakar sufi Timur Tengah yang membahas tentang pengkajian ilmu tasawuf antara lain:

a. al-Ta'arruf li Mażhab al-Taṣawwuf karya Muhammad al-Kalābazì Abū Bakr.

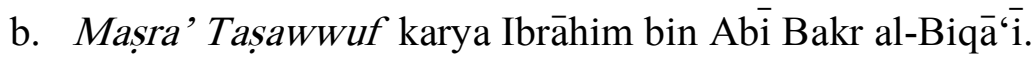

c. Qüt al-Qulūb karya Abū Tāalib al-Makki.

d. Tabaqāt al-Ṣüfiyyah karya Abū 'Abdurraḥmān bin Khālid al-Azdì.

e. Hilyah al-Auliyā' karya $\mathrm{Abu} \mathrm{Nu} \mathrm{Nu}^{\prime} \bar{a}$ al-Aṣbahāni.

f. al-Risālah al-Qusyairiyyah karya al-Qusyairī.

g. 'Awārif al-Ma'ārif karya Syihābuddin 'Umar al-Suwardi.

h. Al-Luma' karya Abū Nașr al-Tüusi.

i. Qawā'id al-Tasawwuf karya Aḥmad Zarrūq.

\footnotetext{
${ }^{24}$ Hamka, Tasauf, Perkembangan dan Pemurniannya, h. 102.

${ }^{25}$ Hamka, Tasauf, Perkembangan dan Pemurniannya, h. 104.

${ }^{26}$ Hamka, Tasauf, Perkembangan dan Pemurniannya, h. 106.

${ }^{27}$ Hamka, Tasauf, Perkembangan dan Pemurniannya, h. 108.

${ }^{28}$ Hamka, Tasauf, Perkembangan dan Pemurniannya, h. 131.

${ }^{29}$ Hamka, Tasauf, Perkembangan dan Pemurniannya, h. 165-166.

${ }^{30}$ Hamka, Tasauf, Perkembangan dan Pemurniannya, h. 148.

${ }^{31}$ Reynold A. Nickolson, Fi Tashawwufil Islamyyi wa Tarikhihi, terjm. Abū al-'A'lā al-Qāî̀, dalam Hamka, Tasauf, Perkembangan dan Pemurniannya (Cet. X; Jakarta: Pustaka Panjimas, 1983), h. 230.
} 
j. Tanwìr al-Qulūb fì Mu'āmalah 'Allām al-Guyūb karya Muhammad Amīn al-Kurdi al-İli.

2. Akar Munculnya Mistisisme Islam

Akar munculnya mistisisme islam adalah berasal dari hadis Nabi Muhammad saw. tentang ihsan. ${ }^{32}$ Ketika itu rasulullah ditanya tentang ihsan oleh Jibril lalu rasulullah menjawab, sembahlah Allah seakan-akan kamu melihat Allah, jika kamu tidak melihatNya, maka sesungguhnya Allah melihatmu. Adapun teks hadis tersebut sebagai berikut:

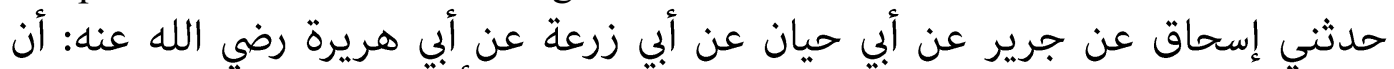

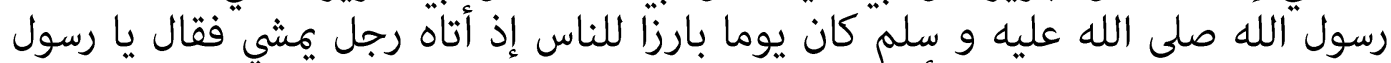

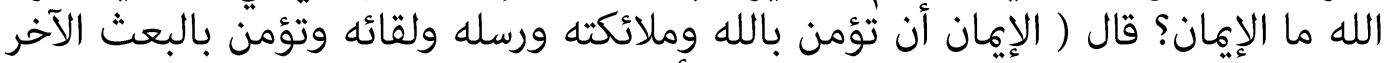

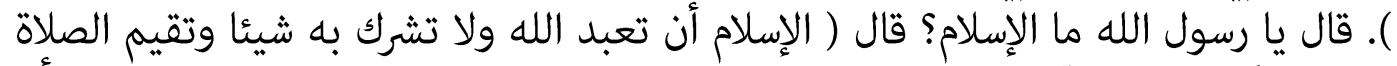

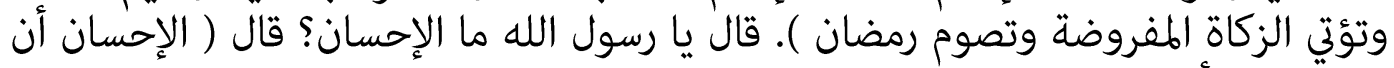

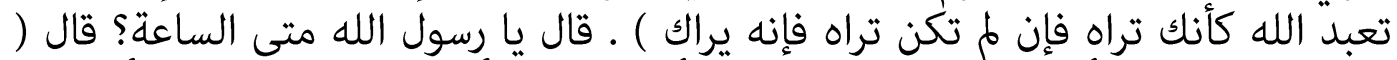

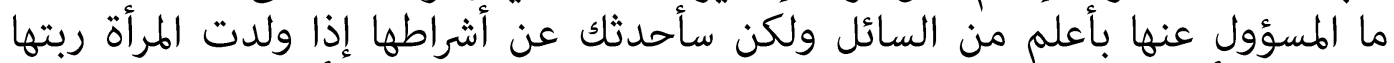

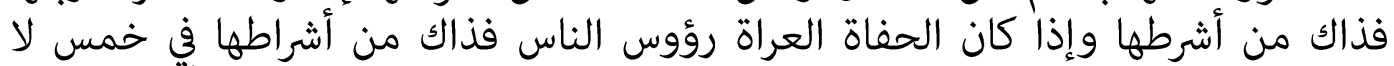

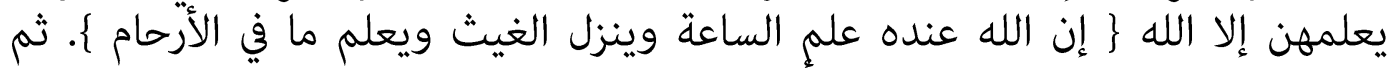

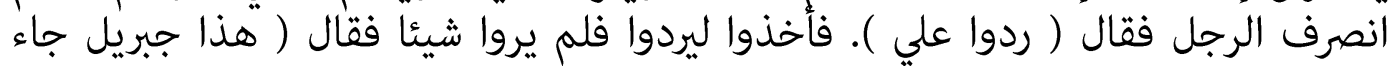

ليعلم الناس دينهم ).

Sejarah mistisme sudah berkembang di seluruh dunia, karena bukan saja para pemikir Islam yang mengkaji hal tersebut, bahkan para pemikir-pemikir barat pun sudah menulis berbagai buku tentang mistisime dan ikut andil dalam ranah ini. Pengkajian mistisisme adalah sebuah pertanyaan besar apakah eksistensi dari mistisisme benar-benar ada? Terdapat beberapa referensi barat mengenai tema mistisisme seperti:

a. Christian Mysticism karya St. Paul, W. R. Inge

b. The Varieties of Religious Expierence karya William James.

c. The Mystical Element of Religion as Studied in Saint Catherine of Genoa and her Friends karya Baron Friendrich von Hugel.

d. Mysticism: The Nature and Development of Spiritual Consciousness karya Evelyn Underhill.

e. West-Ostlich Mystik karya Rudolf Otto.

f. Mysticism Secred and Profane karya Robert Charles Zaehner.

\footnotetext{
${ }^{32}$ Aḥmad bin Aḥmad al-Baransī al-Magribī, Qawā' 'id al-Tasawwuf 'ala Wajh baina al-Syarī ah wa Haqìiqah wa Yasil al-Ușūl wa al-Fiqh bi al-Ṭariqah (Cet. I; Sūria: Dār al-Baransìi, 2004), h. 17.

${ }^{33}$ Lihat Muhạmmad bin Isma'īil Abū 'Abdullāh al-Bukhārī al-Ja'fị, Șahịh al-Bukhārī (Cet. III; Dār Ibn Kasìr, 1987), h. 1793. Hadis tersebut juga diriwayatkan oleh Muslim, al-Nasā' $\bar{i}$, Abū Dāwūd, Ibn Mājah, dan Ạ̣mad bin Ḥanbal.
} 
g. Mysticism and Philosophy karya Walter Terence Stace.

h. The Presence of God karya Bernard McGinn. ${ }^{34}$

Ada beberapa teori yang digunakan dalam menggali akar munculnya mistisime secara universal baik karena pengaruh internal dan eksternal dalam ajaran Islam dan penganutnya. Berikut akan diulas permasalahan tersebut dengan menggunakan beberapa teori:

a. Teori pertama, ajaran tasawuf merupakan produk samping dari persinggungan Islam dengan tradisi agama-agama yang lebih tua di sekelilingnya. Salah seorang yang mendukung teori ini adalah Margaert Smith. Dalam bukunya yang melacak sejarah mistisime di kawasan Timur dan Tengah. Orientalis asal Inggris ini berusaha meyakinkan bahwa ajaran-ajaran sufi (tasawuf Islam) itu sangat dipengaruhi ajaran mistik Kristen. Hal itu dapa dimaklumi mengingat orang Islam pada waktu itu masih terbelakang dan kurang berbudaya dibandingkan dengan orang Kristen yang mereka taklukkan, sehingga mereka terpaksa bergantung pada bantuan dan pertolongan orang-orang Kristen dalam segala urusan.

b. Teori kedua, kemungkinan besar tasawuf Islam berasal dari ajaran Upanishad dan Vedanta Hindu. Sebagaiaman diketahui, Hinduisme antara lain mengajarkan perlunya menjauhi atau meninggalkan sama sekali kenikmatan-kenikmatan badaniah demi meraih kesucian dan ketentraman jiwa.

c. Teori ketiga, ajaran sufi banyak dipengaruhi oleh tradisi hellenisme abad pertengahan. Yang sangat ekstrim seperti Adabert Merx mengklaim bahwa doktrin-doktrin yang dikembangkan para sufi kebanyakan dapat ditemukan presedennya dalam tradisi mistik dan gnostic Yunani.

d. Teori keempat, sufisme merupakan reaksi nasionalisme Arya terhadap dominasi Semit yang dalam hal ini diwakili oleh bangsa Arab dengan agama Islamnya.

e. Teori kelima, sufisme merupakan campuran atau amalgamasi dari beberapa ajaran esoteris yang terdapat dalam tradisi Islam, India (hinduisme dan budisme), Persia (zoroasterianisme), Kristen, neo platonisme, pseudo aristotelisme dan gnostisisme. ${ }^{35}$

\footnotetext{
${ }^{34}$ Lihat Saeed Zarrabizadeh, "Mendefinisikan Mistisisme: Sebuah Tinjauan atas Beberapa Definisi Utama”, Kanz Philosophia 1, no. 1, (1 Agustus-November 2011): h. 95-100.

${ }^{35}$ Syamsuddin Arif, "Manipulasi dalam Kajian tentang Sufisme", Telaah Utama Islamia 3, no. 1 (2006): 23-25.
} 


\section{EPISTIMOLOGI MISTISISME ISLAM}

\section{Analisis Mendalam tentang Mistisime Islam hingga Saat Ini}

Menurut Amin al-Kurdi, Batasan ilmu taswwuf adalah ilmu yang mempelajari keadaan jiwa, sifat terpuji jiwa dan sifat tercelanya, serta bagaimana cara membersihkannya dari sifat tercela, dan menghiasinya dengan dengan sifat terpuji dan bagaimana cara menuju kepada Allah swt. dan teguh kepadaNya. Tema ilmu tasawwuf adalah perbuatan hati dan indera dari segi penyucian dan pembersihan. Buahnya adalah pelatihan hati dan pengetahuan Sang Alim Gaib dengan rasa dan jiwa. ${ }^{36}$

Intisari dalam ilmu tasawuf adalah memahami dan mengetahui suatu kebenaran yang disebut dengan hakikat (truth) dan disertai dengan amalan atau sikap dengan tujuan menyingkap hal yang tersembunyi. Sehingga terdapat tiga tingkatan dalam mencapai puncak pembersihan jiwa yaitu, pensucian jiwa, manifestasi jiwa, dan ketenangan jiwa. Ketiga hal tersebut tidak dapat terwujud kecuali dengan tiga macam perjalanan jiwa yaitu penelusuran hakikat, kerinduan dengan Tuhan, dan hikmah. ${ }^{37}$

Jadi dari penjelasan di atas, dapat dipahami isi pokok dalam aliran mistisisme adalah berakar dari perhatian terhadap akal dan jiwa. Akal dan jiwa merupakan satu kesatuan yang harus tetap dijaga, diperhatikan, mengamati, dan dilatih agar mendapatkan ketentraman, kenyamanan sehingga dalam menjalani hidup dapat mendapatkan jalur yang sesuai sehingga tidak keluar dari ketentuan yang sudah Tuhan tetapkan dan inginkan. Selanjutnya kebahagian hidup merupakan suatu tujuan dan bagaimana cara memaknai kehidupan agar tidak menjadi penghambat bertemunya hamba dengan Tuhan secara maknawi.

Berdasar dari dua sumber tersebut yaitu akal dan jiwa, perlu dipahami secara mendalam dan penuh penghayatan bahwa akal di sini dimaksudkan untuk memikirkan Zat Yang Maha Kuasa dan Bijaksana yaitu Allah swt. dan memikirkan semua yang berwujud besar dan semua benda yang berwujud kecil bahkan yang tidak dapat dilihat oleh mata, semuanya bersumber dari satu Zat yaitu Pencipta benda itu, Allah swt. Selanjutnya beranjak kepadad jiwa. Jiwa merasakan dan seakan hadir dan menyaksikan dengan semua panca indra dan tubuh adanya wujud yang esa, darinya itu ada Zat Yang Esa. Dari Zat yang Esa itu terpancar symbol kehadiran dan kekuasaannya. Sehingga seorang salik

\footnotetext{
${ }^{36}$ Amīn al-Kurdi, Tanwìr al-Qulūb fi Mu'āmalah 'Allām al-Guyūb, h. 465.

${ }^{37}$ Iḥsān Ilāhī Zahīr. "al-Taṣawwuf: al-Mansya' wa al-Maṣādir”, al-Difā’ an al-Sunnah, http://www.d-sunnah.net
} 
mengetahu dengan ilmu dan keyakinan dan persaan bahwa ada yang menguasai semua wujud baik yang berakal maupun yang tidak berakal semuanya berasal dari satu.

Teori tersebut diterapkan oleh seorang ulama yang bernama Ibn 'Arabi $\bar{i}$ dengan teori emanasinya (pancaran). Ibnu 'Arabi bolehlah dihitung sampai di puncak faham wahdah al-wujūd yang tumbuh dalam fikiran ahli-ahli tasawuf Islam. Dia telah menegakkan fahamnya dengan berdasarkan renungan fikir filsafat dan żau (rasa) tasawuf. ${ }^{38}$ Baginya wujud (Yang Ada) itu hanya Satu. Wujudnya makhluk adalah 'ain (kesamaan, yaitu dalam artian manifestasi) wujudnya khalik. Pada hakikatnya tidak ada perbedaan di antara keduanya. Kalau dikatakan berlainan dan berbeda wujud makhluk dan wujud khalik, itu hanya lantaran pendeknya faham dan singkat akal dalam mencapai hakikat. ${ }^{39}$

Keterangan Ibn 'Arabì amat sulit dipahami karen menyatakan segala sesuatu itu adalah satu dengan paham wahdah al-wujūdnya. Ibn 'Arabi berkata tidak ada perbedaan 'ābid (penyembah) dan ma'būd (Yang Disembah), bahkan 'àbid dan ma'būd adalah satu. Perbedaan itu hanya rupa dan ragam dari hakikat yang esa. ${ }^{40}$ Hal ini agak rumit untuk dipaham, akan tetapi jika kita mengamati kembali tentang teori emanasi didapatkan bahwa segala sesuatu merupakan pancaran dari yang pertama, kemudian yang kedua, dan seterusnya. Hal ini mengindikasikan bahwa sagala sesuatu tercipta dari satu. Jika kita melihat seorang makhluk atau benda maka itu berasal dari yang satu dan hakikatnya adalah benar satu.

Selanjutnya, pemahaman yang mendalam akan bisa dimengerti apabila seseorang telah melalui atau merasakan jalur yang ditempuh oleh Ibn 'Arabi dalam teorinya yaitu emanasi. Tetapi tidak bisa dielakkan bahwa Ibnu 'Arabi merupakan filosof dan sekaligus Ahli Tasawuf yang namanya sudah terdengar dimana-mana, dan pendapat atau karya-karyanya yang sudah melegenda. Sehingga dalam istilah kalangan filosof wahdah al-wujūdi artinya segala sesuatu adalah satu. Yaitu ada Tuhan.

Menurut Muhammad Amīn al-Kurdì dalam kitāb Tanwìr al-Qulūb fi Mu'ämalah 'Alläm al-Guyūb ditulis bahwa al-muwaḥhid (orang yang mengesakan) adalah orang yang tenggelam pada yang esa yang telah nampak, Pikirannya hanya satu (yaitu Allah), maka ia tidak mencintai kecuali kepada

\footnotetext{
${ }^{38}$ Hamka, Tasauf, Perkembangan dan Pemurniannya, h. 153.

${ }^{39}$ Hamka, Tasauf, Perkembangan dan Pemurniannya, h. 154.

${ }^{40}$ Hamka, Tasauf, Perkembangan dan Pemurniannya, h. 154.
} 
Allah, dan tidak takut kecuali kepadaNya. Dan tidak mengharapkan rezki selainNya. $^{41}$

Teori al-Hulūl atau al-Ittihăd yang dipopulerkan oleh para pakar sufi adalah serupa dengan paham wahdah al-wujūd yang dibahas oleh para filosof handal dalam dunia filsafat Islam. Fauzi Muhammad Abū Zaìd, seorang sufi kontemporer dari Mesir, menulis dalam bukunya Isyärät al-'Arifïn bahwa, para sufi adalah orang yang telah sampai pada derajat firman Allah, kemanapun engkau berada di sanalah Allah swt. berada. Orang tersebut tidak melihat dalam alam ini kecuali terdapat tanda keberadaan Tuhannya dalam eksistensi ini, yaitu melihat kepada manusia akan tetapi dengan mata hati sehingga ia melihat tanda Maha Mendengar dalam pendengaran, dan Yang Maha Mendengar itu adalah Allah swt, ia melihat tanda Maha Melihat pada penglihatan itu, dan Yang Maha Melihat adalah Allah swt., dan ia melihat tanda kehidupan pada kehidupan manusia ini, akan tetapi ia tidak mengatakan manusia adalah Tuhan, tetapi ia melihat kepada tanda-tanda, sebagaimana firman Allah swt. dalam al-Qur'an, maka lihatlah kepada tanda-tanda rahmat Allah swt. ${ }^{42}$

Selanjutnya dalam pemabhasan al-musyāhadah, Zarrūq menjelaskan bahwa 'Umar bin 'Úsmān al-Makkī berkata al-musyāhadah adalah bertemunya hati secara gaib dengan gaib dan tidak menjadikannya nyata dan konret. Selanjutnya 'Umar bin 'Úsmān al-Makki berkata juga bahwa al-musyāhadah adalah sampainya mata hati dan pandangan mata, kareana pandangan mata hati ketika mengungkap keyakinan dalam tambahan fikiran. ${ }^{43}$

Berdarasarkan penjelasan tersebut, maka dapat dijabarkan bahwa sangatlah sulit untuk memahami dan melaksanakan tasawuf sebagaimana yang dikejelaskan oleh pakarnya. Serta tidak semua manusia dapat melaksanakannya kecuali orang-orang yang selalu berusaha menjauhkan diri dari dosa dan berusaha untuk melatih fikiran dan jiwanya.

2. Sasaran Utama dalam Mistisisme Islam

Dunia kemistikan dibagi dalam tiga tipe transformasi atau penyatuan yaitu:

\footnotetext{
${ }^{41}$ Amin al-Kurdì dalam kitāb Tanwìr al-Qulūb fi Mu'àmalah 'Allām al-Guyūb, h. 461.

${ }^{42}$ Fauzi Muḥammad Abū Zaìd, Isyārāt al- 'Arifî̀n (al-Qahirah: Dār al-Īmān wa al-Ḥayāh, 2016), h. 71.

${ }^{43} \mathrm{Abū} \mathrm{Nāsir} \mathrm{al-Sarrāj} \mathrm{al-Ṭ̂ūî̀,} \mathrm{al-Luma'} \mathrm{(Dār} \mathrm{al-Kutub} \mathrm{al-Ḥadis} \mathrm{bi} \mathrm{Miṣr} \mathrm{wa} \mathrm{Maktabah} \mathrm{al-Masnā} \mathrm{bi}$ bagdād), h. 100.
} 
a. Tipe etis, berupaya untuk menciptakan manusia paripurna agar ia mampu berjumpa dengan yang ada melalui sandi atau yoga seperti aliran Subud.

b. Tipe cosmis, berupaya melebur diri agar dapat menyatu ke dalam jiwa alam universal secara transenden ada yang melalui jalur emanasi menuju sangkan paran, karena manusia adalah pletikanNya. Oleh karena itu tujauan akhirnya adalah sunyata atau suwung. Hindu Sangkaya dan Budisme Mahayana dapat ditunjuk sebagai prototipe aliran ini.

c. Tipe pantheistis, dalam kebatinan disebut menyatu dengan sukma kawekas atau jumbuhing kawula gusti, sedangkan dalam tasawuf disebut iitị̆ād. Menyatunya kawula gusti diawali dari situasi trans, yang kemudian meningkat ke keadaan ekstase. ${ }^{44}$

Penyatuan jiwa bisa dilakukan dengan berbagai cara pendekatan seperti misalnya dengan zikir. Zikir merupakan media untuk mendekatkan seorang hamba kepada Tuhannya. Zikir dalam ilmu tasawuf dibagi atas tiga bentuk, yaitu 1) zikir lisan lā ilāha illallāh. Setelah terasa meresap pada diri, terasa panasnya zikir itu ke tiap-tiap helai bulu roma di badan, zikir itu mulanya pelan-pelan makin lama makin cepat, 2) zikir qalbu atau hati, Allah, Allah. Mulanya mulut berzikir diikuti hati, kemudian dari hati ke mulut, lalu lidah berzikir sendiri, dengan zikir tanpa sadar, akal pikiran tidak jalan lagi melainkan terjadi sebagai ilham yang tiba-tiba nur ilahi dalam hati memberi tahukan innani $\bar{i}$ anallāhu yang naik ke mulut mengucapkan Allah, Allah. 3) zikir sir atau rahasia, $h \bar{u}$. Biasanya sebelum sampai ke tingkat zikir ini, orang sudah fanā'. Dalam keadaan seperti ini, persaan antara diri dengan Dia menjadi satu, man lam yazuq lam ya'rif (barangsiapa belum merasakan, belumlah ia mengetahui). Dalam hal ini tak sanggup lidah menguraikannya, jauh di atas ukuran kata-kata, tetapi tiap orang kan mengerti sendiri bilamana telah mengalaminya. ${ }^{45}$

Tujuan tasawuf adalah fanā' adalah untuk mencapai ma'rifatullāh yaitu leburnya pribadi pada kebaqaan Allah dalam keadaan hulül dimana perasaan keinsanan lenyap. Semua rahasia yang membatasi diri dengan Allah menjadi satu dalam baqaNya bersatu 'ābid dan ma'būd dimana seseorang telah sampai kepada hakikat sebagai ujung dari semua perjalanan. ${ }^{46}$ Adapun tujuan akhir ialah makrifat yaitu puncak dari segala-galanya, dimana sālik (orang yang menjani tasawuf) dapat merasakan Tuhan. Makrifat dapat dicapai dengan jalan syariat,

\footnotetext{
${ }^{44}$ C. Geert, Rekigion of Java, terj. A. Rivay Siregar, Tasawuf dari Sufisme Klasik ke Neo Sufisme (Cet. II; Jakarta: PT. Raja Grafindo Persada, 2002), h. 22-23.

${ }^{45}$ Mustafa Zahri, Kunci Memahami Ilmu Tasawwuf, h. 65.

${ }^{46}$ Mustafa Zahri, Kunci Memahami Ilmu Tasawwuf, h. 64.
} 
menempuh tarikat, memperolah hakikat. Jadi syariat adalah peraturan, tarikat adalah pelaksanaan, hakikat adalah keadaan, makrifat adalah puncak segalanya. ${ }^{47}$

Menurut simuh tujuan akhir tasawuf adalah mencapai penghayatan fana fillāh yaitu kesadaran leburnya diri mereka dalam samudera ilahi. ${ }^{48}$ Menurut A. Rivay Siregar tentang tujuan tasawuf adalah agar berada sedekat mungkin dengan Allah. Akan tetapi apabila diperhatikan karakteristik tasawuf secara umum, terlihat adanya tiga sasaran dari tasawuf itu yaitu, pertama aspek moral. Aspek ini meliputi mewujudkan kestabilan jiwa yang berkesimbangan, penguasaan dan pengendalian hawa nafsu sehingga manusia konsisten dan komitmen hanya kepada keluhuran moral. Tasawuf yang betujuan moralitas ini, pada umunya bersifat praktis. Kedua, tasawuf yang bertujuan ma'rifatullāh melalui penyingkapan langsung atau metode kasyf al-hijāb. Tasawuf jenis ini sudah bersifat teoritis dengan seperangkat ketentuan khusus yang yang diformulasikan secara sistematis analitis. Ketiga, tasawuf yang bertujuan unt uk membahas bagaimana sistem pengenalan dan pendekatan diri kepada Allah secara mistis filosofis, pengkajian garis hubungan antara Tuhan dengan makhluk, terutama hubungan manusia dengan Tuhan dan apa arti dekat dengan Tuhan itu, terdapat tiga simbolisme yaitu, dekat dalam arti melihat dan merasakan kehadiran Tuhan dalam hati, dekat dalam arti berjumpa dengan Tuhan sehingga terjadi dialog antara manusia dengan Tuhan dan makna dekat yang ketiga adalah penyatuan manusia dengan Tuhan sehingga yang terjad adalah monolog antara manusia yang telah menyatu dalam irädah Tuhan. ${ }^{49}$

Tujuan utama yang menjadi pusat ideal orang-orang yang menjalankan mistik atau tasauf adalah mendapatkan penghayatan makrifat langsung pada Zat Allah tau Zat Mutlak. Para sufi lebih sering menamakan Zat Allah sebagai alHaqq (reality), yakni realitas mutlak yang bisa dihayati. Hanya saja mata manusia menurut al-Gazali tidak akan bisa menangkap cahaya Tuhan lantaran terlalu terang, laksana kalelawar di siang hari tidak bisa menangkap cahaya matahari lantaran terlalu terang tak sesuai dengan kemampuan mata kalelawar. Maka yang bisa menangkap dan menghayati zat Tuhan dan alam gaib adalah kalbu (mata hati), yakni jiwa manusia. Dengan demikian intisari yang menjadi pusat dalam ajaran tasawuf adalah penghayatan kasyfyaitu penghayatan atau istilah tasawufnya fana dan makrifat. Fana dan makrifat adalah pengalaman dan

\footnotetext{
${ }^{47}$ Mustafa Zahri, Kunci Memahami Ilmu Tasawwuf, h. 65.

${ }^{48}$ Simuh, Tasawuf dan Perkembangannya dalam Islam (Cet. II; PT. Raja Grafindo Persada, 1997), h. 40 .

${ }^{49}$ A. Rivay Siregar, Tasawuf dari Sufisme Klasik ke Neo Sufisme (Cet. II; Jakarta: PT. Raja Grafindo Persada, 2002), h. 57.
} 
kejiwaan. Oleh karena itu jalan yang harus ditempuh adalah meditasi konsentrasi di dalam zikir kepada Allah. Dalam tasawuf jalan menuju Tuhan ini mereka namakan tariqah (the path). ${ }^{50}$

Hamka berpendapat bahwa tasawuf adalah salah satu filsafat Islam, yang maksudnya untuk zuhud dari dunia yang fana. Tetapi lantaran banyaknya bercampur dengan bangsa lain, banyak sedikitnya masuk jugalah pengajian agama dari bangsa lain itu ke dalamnya. Karena tasawuf bukanlah agama, melainkan suatu ikhtiar yang setengahnya diizinkan agama dan setengahnya pula tidak sadar, telah tergelincir dari agama, atau terasa enaknya pengajaran agama lain dan terikuti dengan tidak diingat. ${ }^{51}$

\section{AKSIOLOGI MISTISISME ISLAM MODERN}

Tujuan utama dalam wujud lahirnya mistisisme modern adalah peningkatan mutu serta penguatan ulang ajaran Islam agar dapat dipahami dengan baik oleh generasi saat ini. Hal ini dianggap perlu karena tuntutan zaman yang lebih cenderung kepada pola pikir dan gaya hidup yang serba canggih sehingga lahirlah lingkungan modern dan upaya pembersihan dan pembuangan analisis pemikiran klasik kepada seuatu yang bersifat rendah. Sehingga lahirlah pemikir-pemikir Islam modern yang berusaha mengimbangi keadaan yang dapat menghapuskan asas atau prinsip-prinsip fundamental ajaran Islam yang telah memiliki rentetan akar yang kuat atau sanad yang telah berkembang dari era klasik hingga era modern ini. salah satu pemikir tersebut adalah Muhammad Abduh. Muhammad Abduh adalah seorang pembaharu pendidikan Islam dan perumus ajaran Islam modern dalam pengertian dengan meningkatkan mutu pendidikan Islam dan mengemukakan kembali ajaran-ajaran dasar Islam dengan bahasa yang jelas dan tegas, pengaruh-pengaruh yang merusak, baik yang bersifat animistik maupun materialistik, dapat dikeluarkan dan dilenyapkan. ${ }^{52}$

Beranjak dari usaha seorang pemikir Islam di atas, dalam faham ajaran Islam yang membentuk sebuah aksiologi penerapan ajaran islam sehingga dinamakan mistisisme Islam atau sufi. Aliran sufisme telah eksis di zaman awal kelahiran Islam dan telah mengalami kemunduran setelah lahirnya era modern dan ilmu pengetahuan modern bahkan hampir menutup semua jalur tumbuhnya aliran ini. Tetapi setelah mengalami masa tersebut aliran ini kembali bangkit

\footnotetext{
${ }^{50}$ Simuh, Tasawuf dan Perkembangannya dalam Islam, h. 39.

${ }^{51}$ Hamka, Tasauf, Perkembangan dan Pemurniannya, h. 18.

${ }^{52}$ H. A. R. Gibb, Aliran-Aliran Moderen dalam Islam (Cet. I; Jakarta: CV. Rajawali, 1990), h. 69.
} 
dengan istilah baru yaitu dengan nama neo sufisme atau kebangkitan agama atau bisa juga disebut dengan mistisisme Islam modern.

Kebangkitan kembali sufisme di dunia Islam dengan sebutan neo sufisme, nampaknya tidak bisa dipisahkan dari apa yang disebut sebagai kebangkitan agama sebagai penolakan terhadap kepercayaan yang berlebihan kepada sains dan teknologi selaku produk era modernisme. Modernisme dinilai gagal memberikan kehidupanyang bermakna bagi manusia, karenanya orang kembali ke agama. Karena, salah satu fungsi agama adalah memberikan makna bagi kehidupan. ${ }^{53}$

Adapun kesamaan dan perbedaan antara sufisme klasik dan kebangkitan neo sufisme adalah sebagai berikut:

1. Kelahiran sufisme klasik dan kebangkitan neo sufisme nampaknya dimotivasikan oleh faktor-faktor yang sama, yakni gaya kehidupan yang glamour dan materi alistik-konsumeristik, formalism pemahaman dan pengamalan keagamaan sebagai imbas dari kegarangan rasionalisme, dan factor kekerasan perebutan hegemoni kekuasaaan yang merasuki seluruh aspek kehidupan manusia.

2. Kesucian jiwa rohaniah, bahwa keduanya sama dan mendambakan dan menekankan betapa urgennya kebeningan dan kesucian hati nurani dalam segala aspek kehidupan umat manusia.

3. Pendekatan esetoris, keduanya sama berkeyakinan bahwa untuk memahami dan menghayati makna keagamaan harus melalui pendekatan esetoris, pendekatan pengalaman metafisis atau al-kasyf. Namun dalam hal kemutlakan nilai kebenarannya, terlihat antara keduanya ada perbedaan yang cukup tajam. Kalau sufisme terdahulu meyakini meyakini secara mutlak kebenaran yang diperoleh melalui esoteris al-kasyf, tetapi neo sufisme akan meyakini kebenaran itu apabila sejajar dengan syariat. Di samping itu sufisme terdahului hanya mengakui pendekatan esoteric satu-satunya yang dapat digunakan dalam rangka penghayatan keagamaan, tetapi neo sufisme tetap mengakui terhadap pluralitas pendapat.

4. Zikrullāh dan muraqabah, keduanya sama-sama meyakini betapa pentingnya masalah ini dalam segala situasi demi tercapainya rida Allah swt.

\footnotetext{
${ }^{53}$ A. Rivay Siregar, Tasawuf dari Sufisme Klasik ke Neo Sufisme, h. 312.
} 
5. Sikap 'uzlah, kalau sufisme terdahulu menempu cara hidup 'uzlah total, maka neo sufisme menempuh cara itu hanya sewaktu diperlukan saja sekedar untuk menyegarkan wawasan melalui muhasabah (introspeksi).

6. Zuhud, askestisme, apabila sufi terdahulu membenci kehidupan duniawi karena dianggap menghalangi pencapaian tujuan, tetapi sufisme baru meyakini kehidupan duniawi ini sangat sangat bermakna dan amat penting. Oleh karena itu, kehidupan duniawi harus diperjuangkan tetapi harus disesuaikan dengan kepentingan ukhrawi. Menurut pandangan ini, makna kehidupan duniawi tergantung pada keterkaitannya dengan nilai ukhrawi yang dihasilkan aktifitas duniawi itu. Karena mereka berkeyakinan, bahwa neo sufisme menjadi satu-satunya menjadi alternatif culture materealistis-konsumeris dan hedonis. ${ }^{54}$

Ada beberapa tarikat sepanjang dunia Islam yang terkenal, misalnya tarikat-tarikat Islam yang berkembang di Indonesia sampai saat ini yang masih mengambil peran dalam dunia tasawuf atau mistik Islam, seperti tarikat Qādiriyyah yang menyebar di $\mathrm{aceh}^{55}$, Syaziliyyah yang menyebar , Naqsyabandiyyah di Gowa Sulawesi Selatan ${ }^{56}$, Khalwatiyyah yang banyak dianut oleh suku Bugis Makassar ${ }^{57}$, Syattariyyah di Aceh ${ }^{58}$, Sammaniyyah di Aceh dan Palembang ${ }^{59}$, Tijaniyyah Buntet di Cirebon ${ }^{60}$, Qadiriyyah wa Naqsyabandiyyah (TQN) di Kota Sambas Pontianak ${ }^{61}$. Adapun tarikat yang berkembang di dunia sperti tarikat Chistiyyah di India, Mawlawiyyah di Turki, Ni'matullah di Persia, Sanusiyyah di Afrika Utara.

Sejarah awal masuknya tasawuf di Indonesia menurut hamka, bahwa tasuwuf masuk ke Indonesia sejak abad permulaan perkembangannya, abad ketiga belas dan abad keempat belas, sampai pada zaman terakhir. Sampai

\footnotetext{
${ }^{54}$ A. Rivay Siregar, Tasawuf dari Sufisme Klasik ke Neo Sufisme, h. 319-320. Tidak pula boleh disalah artikan bahwa kekayaan tidak boleh dimiliki seorang sufi, di era modern, sufi memanfaatka kekayaan mereka untuk mendekatka diri kepada Allah dan bukan berarti mereka jauh dari zuhud yaitu jauh dari sifat tidak terpengaruh oleh dunia dan cinta akhirat, akan tetapi, menjadikan fasilitas dunia sebagai ladang pahala di akhirat dan memetik hasilnya di sana.

${ }^{55}$ Sri Muyati, Mengenal dan Memahami Tarekat-Tarekat Muktabarah di Indonesia (Cet. II; Jakarta: Prenada Media, 2005), h. 52.

${ }^{56}$ Sri Muyati, Mengenal dan Memahami Tarekat-Tarekat Muktabarah di Indonesia, h. 95.

${ }^{57}$ Sri Muyati, Mengenal dan Memahami Tarekat-Tarekat Muktabarah di Indonesia, h. 118.

${ }^{58}$ Sri Muyati, Mengenal dan Memahami Tarekat-Tarekat Muktabarah di Indonesia, h. 162.

${ }^{59}$ Sri Muyati, Mengenal dan Memahami Tarekat-Tarekat Muktabarah di Indonesia, h. 191-192.

${ }^{60}$ Sri Muyati, Mengenal dan Memahami Tarekat-Tarekat Muktabarah di Indonesia, h. 223.

${ }^{61}$ Sri Muyati, Mengenal dan Memahami Tarekat-Tarekat Muktabarah di Indonesia, h. 253.
} 
pulalah ke Indonesia ini tarikat-tarikat tasawuf, ada Naqsyabandiyah yang datang dari Asia Tengah, ada Qadariyyah yang berasal dari Bagdad, ada Idrusiyah yang berasal dari Hadramaut, ada Rifa'iyah yang didatangkan dari Mesir di zaman Pasai yang sampai sekarang menjadi nama dari satu gendering atau rebana, yang diberi nama Rifai. ${ }^{62}$

Sejarah berkembangnya mistisisme modern terkadang muncul karena dilatar belakangi oleh kerinduan jiwa yang ingin tenang terhadap perkembangan dunia modern seperti yang dijelaskan hamka dalam bab, Mengembalikan Tasauf Ke Pangkalnya Di Indonesia, bahwa dalam zaman kekacauan zaman kekacauan fikiran, lantaran kekacauan ekonomi, sosial dan politik, kerap kali timbul kerinduan umat hendak melepaskan fikiran dari pengaruh kenyataan, lalu masuk dalam daerah khayalan tasauf. Karen sempit fikiran di bumi, orang pun menengadah ke bintang gemerlap di langit, hendak mencari bahagia di sana. Itu sebabnya dimana-mana di zaman sekarang, timbul gerakan kebatinan sebagai cendawan tumbuh di musim hujan. Sebagian besar dari mereka masih termasuk dalam lingkungan pemeluk Islam juga. Maka oleh karena mereka merasa tidak puas dengan Islam yang hanya semata-mata diberatkan pada halal haram, kepada hukum-hukum fikih, mereka lari kepada ilmu kebatinan (tasauf). ${ }^{63}$

Sumber dalam ajaran tasawuf adalah ilmu dan praktiknya ${ }^{64}$, sama halnya yang dilakukan oleh sufi modernis mereka juga mempelajari tasawuf dan memperaktikkan apa yang mereka pelajari. Hal ini merupakan pelaksanaan ajaran Islam yang mengajarkan bahwa tiadalah artinya iman tanpa amal dan amal tanpa ilmu semuanya harus diwujudkan dan dilaksanakan dalam kehidupan dunia ini.

Secara umum tingkatan atau maqam yang ditempuh dalam mendekatkan diri kepada Allah adalah, taubat, wara' (berhati-hati dalam bertindak), fakir, zuhud (tidak menjadikan dunia tujuan utama), sabar, tawakkal, rida. ${ }^{65}$ Tasawuf Islam modern dalam aplikasinya juga memperaktekkan yang telah aplikasikan oleh ulama tasawuf klasik, tetapi letak perbedaan mereka adalah terletak pada metode yang dilalui. Metode tasawuf modern lebih mengarahkan aliran tasawuf mereka dengan menyesuaikan keadaan tarikat dengan zaman modern sehingga

\footnotetext{
${ }^{62}$ Hamka, Tasauf, Perkembangan dan Pemurniannya, h. 236.

${ }^{63}$ Hamka, Tasauf, Perkembangan dan Pemurniannya, h. 250.

${ }^{64}$ Hal tersebut disebutkan oleh Imam al-Gazali dalam karyanya. Lihat Abū Hamīd Ahmad alGazāìi, Majmū'ah Rasāil al-Imām al-Gazālì : al-Munqiz min al-Ḍalāl, al-Aḥāìis al-Qudsiyyah, Qānūn al-Ta'wìl, h. 58.

${ }^{65}$ Media Zainul Bahri, Menembus Tirai Kesendiriannya Mengurai Maqamat dan Ahwal dalam Tradisi Sufi, dalam Tasmin Tangngareng, "Puncak-Puncak Caoaian Sufistik dalam Perspektif Metodologis", Jurnal Aqidah-Ta III, no. 1 (2017) : 85-88.
} 
tidak terjadi benturan antara tarikat dengan zaman modern yang jauh dengan rasa kerohanian dan seakan jauh dari rasa cinta dan dekat dengan Tuhan.

Tidak ada letak perbedaan yang jauh antara tasawuf klasik dan tasawuf modern secara umum, hanya saja di kalangan tasawuf modern lebih menyeimbangkan dan berusaha untuk menyesuaikan diri dengan zaman modern sehingga dalam menilai dan menimbang sesuatu di zaman modern sesuai dengan landasan syariat atau al-Qur'an dan hadis. Seperti dalam penggunaan fasilitasfasilitas yang serba canggih begitu juga transportasi yang dulunya belum muncul di zaman sufi klasik, boleh dipergunakan oleh sufi modern tanpa mengurangi pahala yang dimaksudkan untuk mendekatkan diri kepada Allah swt. Dalam hal ini, zaman modern bagi sufi kontemporer adalah nikmat yang besar yang Allah berikan kepada hambanya sehingga memudahkan mereka sampai kepada Allah denga perantaraan zaman ini dengan tetap menggunakan tiga landasan umum dalam ilmu tasawuf yaitu, syariat, tarikat, dan hakikat.

Tarikat sebelumnya dalam tasawuf sama dengan tarikat sekarang secara prinsip dan berbeda sccara praktik karena akan disesuaikan dengan zaman. Hal ini sesuai dengan mistisisme modern, yaitu barat dan Islam secara umum. Dalam mistisisme barat modern dalam praktiknya lebih menekankan pada cara berfikir yang tidak dogmatis tetapi metodik. Sebagaiaman Francis Grierson berpendapat bahwa mistisisme modern tidak hanya anti provincial (bermazhab kedaerahan) tetapi juga ia sebaik-baik anti dogmatik. ${ }^{66}$ Adapun dalam mistisme Islam dalam menyikapi modernitas lebih bertumpu pada legalitas syariat agama Islam yaitu al-Qur'an, hadis, dan kesepakatan ulama atau mujtahid dari golongan pakar agama Islam. Laila Qarāwazān dan Muhammad Zamrī mengatakan berpendapat bahwa pembaharuan pada ruh tasawwuf adalah gadaian ilmiah dan peradaban yang mengangkat semua lapisan, oleh karena itu seharusnya ada penyaringan terutama pemikiran yang lahir dari fitnah manusia, atau pembaharuan itu tidak sejalan dengan prinsip-prinsip Islam dalam hak asasi manusia dan sopan santun. ${ }^{67}$

Mengenai perkembangan ilmu tasawuf modern terdapat beberapa karya ulama tasawuf dan hakikat yang telah ditulis untuk menjelaskan kemukjizata dan hakikat al-Qur'an. Adapun di antara ulama tersebut adalah Said Nursi seorang ulama Turki yang wafat pada tahun 1960, dengan karyanya yang dikumpul dalam sebuah koleksi yang bernama Risalah Nur yang memuat 11 jilid kitab yang

\footnotetext{
${ }^{66}$ Francis Grierson, Modern Mystisicm

and Other Essyays, IV Edition (New York: John Lane Company, 1914), h. 14

${ }^{67}$ Lailā Qarāwazān dan Muhammad Zamrī, “al-Taṣawwuf fì Mir’āh al-Mu‘āṣarah”, Jāmi 'ah alNajạh li al-Abhạ̄s (al- 'Ulūm al-Insāniyyah) XXVII, no. 3 (2013): h. 497.
} 
membahasa kemukjizatan al-Quran serta hakikat dan latifah (makna yang mendetail) dalam al-Qur'an. Selanjutnya Fauzi Muhammad Abū Zaìd seorang sufi kontemporer Mesir. Adapun karyanya tentang tasawuf modern adalah alȘüfiyyah wa a-Hayāh al-Mu'ạsarah, al-Șafà' wa al-Asfiyā', Abwāb al-Qurb wa Manāzil al-Taqrīb, al-Ṣüfiyyah fi al-Qur'ān wa al-Sunnah, dan selainnya.

Adapun perbincangan tarikat yang keluar dalam syariat maka itu bukanlah aliran sufisme atau dalam ranah mistisisme Islam. ${ }^{68}$ Karena syarat dalam tasawuf adalah harus sejalan dengan syariat Islam. Adapun yang tidak sejalan dengan hal tersebut maka tarikat yang dijalani telah keluar dari ajaran Islam. Hal ini telah dijelaskan dalam kitab-kitab tasawuf klasik dan kontemporer karya para ulama sufi Islam. ${ }^{69}$ Al-Zarrūq mengatakan bahwa tidak ada tasawuf kecuali dengan fikih, karena hukum zahir Allah tidak akan diketahui kecuali dari fikih. Dan tidak ada fikih kecuali dengan tasawuf, karena tidak ada perbuatan tanpa kebenaran dan penghadapan. Dan keduanya tidak akan eksis tanpa iman, karena salah satu dari keduanya tidak sah tanpa iman. Maka seharusnya keduanya ada dalam hukum bagaikan ruh dalam badan. ${ }^{70}$

\section{PENUTUP}

\section{A. Kesimpulan}

1. Mistisisme Islam merupakan sebuah ilmu yang mempelajari cara mendekatkan diri kepada Allah sebagai bentuk rindu dan cinta kepadaNya dan hanya mengaharapkan ridaNya. Ilmu ini dianamakan ilmu tasawuf yang berdasarkan kepada hadis sahih yang menceritakan dan menjelaskan ihsan sebagai bentuk keikhlasan beribadah kepadaNya. Ilmu ini merupakan ilmu yang mulia karena menjalankan tujuan dan syariat Islam secara bersamaan dengan menggunakan tiga metode yaitu, tarikat, syariat, dan hakikat. Dan mistisisme ini merupakan ilmu yang memiliki metode tersendiri yang sesuai dengan tarikat yang dijalani. Tetapi harus tetap berada dibawah kontrol syariat Islam.

2. Mistisisme Islam memiliki dua peran, yang pertama, mengontrol pikiran agar tetap pada koridor syariat Islam, agar senantiasa dalam pemikiran yang jernih jauh dari kekeruhan dan kesamaran sehingga hamba jauh dari Tuhannya dan tidak mengingat sedikitpun tentang Sang Pencipta. Hal ini

\footnotetext{
${ }^{68}$ Lihat penjelesan al-Jurjani mengenai pengertian tasawwuf pada pembahasan sebelumnya pada halaman 3.

${ }^{69}$ Telah kitab-kitab tasauf Islam yang telah disebutkan pada halaman 11.

${ }^{70}$ Aḥmad bin Aḥmad al-Baransī al-Magribī, Qawā'id al-Taṣawwuf 'ala Wajh baina al-Syarī'ah wa Haqiquah wa Yasil al-Ușūl wa al-Fiqh bi al-Tariquah, h. 15.
} 
harus dihindari dan dijernihhkan. Kedua, jiwa manusia membutuhkan pembelajaran dan pelatihan sehingga jiwa tetap merasakan kehadiran Tuhan melalui manifestasinya, sehingga semua indra manusia tidak sedikitpun lepas dari mengingat Tuhan, melalui metode pendekatan dalam ilmu Tasawuf atau maqamatnya. Introspeksi diri juga membantu seorang hamba dekat dan merasa lemah di depan Tuhannya. Ini bisa diterapkan dengan cara memiliki sifat terpuji dan membuang sifat tercela yang ada dalam hati dan pikiran. Tubuh yang terkontrol dengan ilmu Tasawuf akan mudah melaksanakan ketaatan dan ibadah sehingga bisa mendapatkan rida Tuhan dan dilindungi dari berbagai fitnah yang nyata dan yang tersembunyi.

3. Mistisisme Islam modern adalah cara yang ditempuh sorang murid atau sufi pada zaman modern yang disesuaikan dengan era yang maju ini. Memanfaatkan era modern untuk mendekatkan diri kepda Tuhan tidak menjadi penghalang atau tidak mengurangi pahala, karena dunia ini diciptakan untuk menjadi lahan amal dan memproduksi amal sebagai penerapan tuntunan kitab al-Qur'an dan hadis hingga akhir hayat nanti. Semboyan para sufi adalah salah satunya agar tidak menjadikan dunia ini satu-satunya tujuan hidup dan melupakan tujuan abadi yaitu akhirat sebagai sumber kebahagiaan. Jiwa yang tenang adalah jiwa yang senantiasa bahagia kepada Tuhannya yaitu Allah swt. Sehingga walaupun seorang hamba hidup di zaman yang serba canggih tidak mempengaruhinya untuk memikirkan tanda bahwa Tuhan Maha Esa yaitu Allah swt.

\section{B. Implikasi}

Mistisisme Islam modern merupakan perwujudan dari mistisisme Islam klasik yang mempermudah seseorang untuk sampai kepada hakikat atau memahami isyarat-isyarat yang terkandung dalam semua hal dan mengarahkan fikiran dan jiwa untuk sampai kepda Allah swt. Mistisisme Islam modern diperbolehkan dan dianjurkan sebagai tanda kecintaan kepada Allah swt. di zaman orang-orang semakin jauh dan berusaha lupa kepada akhirat dengan mengatas namakan bersenang-senang dengan semua kenikmatan dunia yang menipu karena disibukkan dengan permasalahan politik dan bisnis serta persaingan dunia. Mistisisme ini dibolehkan selama tidak bertantangan dengan aqidah dan syariat Islam yang sudah ditetapkan oleh Pembuat undang-undang yang Maha Bijaksana. 


\section{DAFTAR PUSTAKA}

\section{Al-Qur'ān al-Karìm}

A. Nicholson, Reynold. The Mistic of Islam, terj. Tim Penerjemah BA, Mistik dalam Islam (Cet. I; Jakarta: Bumi Aksara, 1998), h. 21.

A. Nickolson, Reynold. Fi Tashawwufil Islamyyi wa Tarikhihi, terjm. Abū al'A'lā al-Qāề, dalam Hamka, Tasauf, Perkembangan dan Pemurniannya. Cet. X; Jakarta: Pustaka Panjimas, 1983.

Abū Nāṣir al-Sarrāj al-Ṭūsì, al-Luma'. Dār al-Kutub al-Ḥadis bi Miṣr wa Maktabah al-Masnā bi bagdād.

Abū Zāid, Fauzì Muhammad. Isyārāt al-'Arifīn. al-Qahirah: Dār al-Īmān wa alḤayāh, 2016.

Arif, Syamsuddin. "Manipulasi dalam Kajian tentang Sufisme", Telaah Utama Islamia 3, no. 1. 2006.

Bahri, Media Zainul. Menembus Tirai Kesendiriannya Mengurai Maqamat dan Ahwal dalam Tradisi Sufi, dalam Tasmin Tangngareng, "Puncak-Puncak Caoaian Sufistik dalam Perspektif Metodologis", Jurnal Aqidah-Ta III, no. 1. 2017.

al-Baransi al-Magribī, Aḥmad bin Aḥmad. Qawā'id al-Taṣawwuf 'ala Wajh baina al-Syari ‘ah wa Haqūiqh wa Yasil al-Ușūl wa al-Fiqh bi al-Ṭariqah. Cet. I; Süria: Dār al-Baransi, 2004.

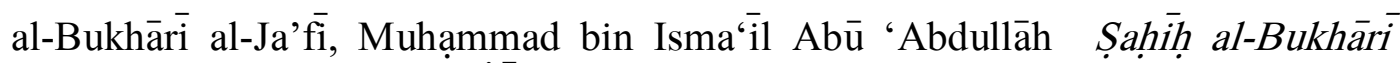
(Cet. III; Dār Ibn Kàìir, 1987), h. 1793. Hadis tersebut juga diriwayatkan oleh Muslim, al-Nasā̄' $\bar{i}$, Abū Dāwūd, Ibn Mājah, dan Ạ̣mad bin Ḥanbal.

C. Geert, Rekigion of Java, terj. A. Rivay Siregar, Tasawuf dari Sufisme Klasik ke Neo Sufisme. Cet. II; Jakarta: PT. Raja Grafindo Persada, 2002.

al-Gazāīi, Abū Hạīì Aḥmad. Majmū'ah Rasāil al-Imām al-Gazālì : al-Munqi் min al-Ḍalāl, al-Ahàadis al-Qudsiyyah. Qānūn al-Ta'wìl. Baìrūt. Dār alKutub al-'Ilmiyyah. 1988.

Grierson, Francis. Modern Mystisicm and Other Essyays, IV Edition. New York: John Lane Company, 1914.

H. A. R. Gibb. Aliran-Aliran Moderen dalam Islam. Cet. I; Jakarta: CV. Rajawali, 1990.

Hamka, Tasauf, Perkembangan dan Pemurniannya. Cet. X; Jakarta: Pustaka Panjimas, 1983.

al-Jurjāni, 'Alì bin Muhammad 'Alì. al-Ta'rifät. Cet. I. Dār al-Kutub al-'Arabī. $1405 \mathrm{H}$. 
Kementerian Agama RI, al-Qur'an dan Terjemahnya. Saudi Arabia: Mujamma' al-Malik Fahd li Thiba'at al-Mush-haf Asy-Syarif Medinah Munawwarah, 1997Abu Bakar Aceh, Pengantar Ilmu Tarekat, dalam Mustafa Zahri, Kunci Memahami Ilmu Tasawwuf(Jakarta: PT. al-Qusywa, 1985.

al-Kurdī, Amīin. Tanwìr al-Qulūb fi Mu'āmalah 'Allām al-Guyūb. Sūriyyah: Dār al-Qalam al-'Arabī. 1991.

Lailā Qarāwazān dan Muhammad Zamrī. "al-Tașawwuf fī Mir’āh al-Mu'āṣarah”, Jämi'ah al-Najạh li al-Abḥās (al- 'Ulüm al-Insāniyyah) XXVII, no. 3. 2013.

Muṣtafā, Ibrāīim. dkk., al-Mu’jam al-Wasịt. Dār al-Da’wah.

Pusat Bahasa Departemen Pendidikan Nasional. Kamus Bahasa Indonesia. Jakarta: Pusat Bahasa. 2008.

Saeed Zarrabizadeh, "Mendefinisikan Mistisisme: Sebuah Tinjauan atas Beberapa Definisi Utama", Kanz Philosophia 1, no. 1, 1 AgustusNovember 2011.

Simuh, Tasawuf dan Perkembangannya dalam Islam. Cet. II; PT. Raja Grafindo Persada, 1997.

Siregar, A. Rivay. Tasawuf dari Sufisme Klasik ke Neo Sufisme. Cet. II; Jakarta: PT. Raja Grafindo Persada, 2002.

Sri Muliyati, Mengenal dan Memahami Tarekat-Tarekat Muktabarah di Indonesia. Cet. II; Jakarta: Prenada Media, 2005.

Ẓahīr, Iḥsān Ilāhì. "al-Taṣawwuf: al-Mansya' wa al-Maṣādir”. al-Difă’ an alSunnah. http://www.d-sunnah.net

Zahri, Mustafa. Kunci Memahami Ilmu Tasawwuf . Jakarta: PT. al-Qusywa. 1985. 